\title{
PHYTOCHEMICAL AND CYTOTOXIC INVESTIGATIONS OF THE HEARTWOOD OF CAESALPINIA SAPPAN LINN.
}

\section{CHULEEPORN NGERNNAK ${ }^{1}$, PAWARET PANYAJAI' ${ }^{2}$, SONGYOT ANUCHAPREEDA ${ }^{2}$, WEERAH WONGKHAM ${ }^{3}$, AROONCHAI SAIAI ${ }^{*}$}

${ }^{1}$ Department of Chemistry, Faculty of Science, Chiang Mai University, Chiang Mai, 50200, Thailand. ${ }^{2}$ Department of Medical Technology, Faculty of Associated Medical Sciences, Chiang Mai University, Chiang Mai 50200, Thailand. ${ }^{3}$ Department of Biology, Faculty of Science, Chiang Mai University, Chiang Mai, 50200, Thailand. Email: aroonchai.s@cmu.ac.th

Received: 04 October 2017, Revised and Accepted: 20 November 2017

\section{ABSTRACT}

Objective: The purpose of this study was to identify the chemical constituents in the dichloromethane extract by gas chromatography-mass spectrometry (GC-MS) analysis and evaluate the cytotoxic effects on leukemia cells of isolated compounds from Caesalpinia sappan Linn.

Methods: Dichloromethane extract obtained from the heartwood of $C$. sappan was investigated by GC-MS and column chromatography. Cytotoxic effects on leukemia cells of the isolated compounds were examined using MTT assay.

Results: The GC-MS analysis of dichloromethane extract from C. sappan revealed the presence of 14 compounds. Linoleic acid and $\beta$-sitosterol were found to be the major compounds presenting in $14 \%$ and $13 \%$, respectively. The separation of the dichloromethane extract led to the isolation of brazilin (1) as a major compound, together with lupeol (2), and a mixture of $\beta$-sitosterol (3), and stigmasterol (4). Their structures were elucidated based on spectroscopic methods. Brazilin (1) showed a cytotoxic effect on human acute myeloid leukemia cell (KG1) and human acute myeloid leukemia stem cell (KG1a) with inhibitory concentration at $50 \%$ growth (IC ${ }_{50}$ ) values of $13.30 \pm 0.49$ and $12.24 \pm 1.08 \mu \mathrm{g} / \mathrm{ml}$, respectively.

Conclusion: Many groups of phytochemical compounds in the dichloromethane extract of C. sappan were detected by GC-MS analysis. Some of them have been reported to possess various biological activities. Moreover, brazilin (1) isolated compound from C. sappan shows cytotoxicity on leukemia cells, which could be a potential anticancer property.

Keywords: Caesalpinia sappan, Gas chromatography-mass spectrometry, Brazilin, Cytotoxicity, Leukemia cells.

(c) 2018 The Authors. Published by Innovare Academic Sciences Pvt Ltd. This is an open access article under the CC BY license (http://creativecommons. org/licenses/by/4. 0/) DOI: http://dx.doi.org/10.22159/ajpcr.2018.v11i2.22903

\section{INTRODUCTION}

Caesalpinia sappan Linn., locally known as "Fang," is used as a medicinal plant in Thailand. A decoction of the heartwood of C. sappan has long been used in Thai folk medicine to treat tuberculosis, diarrhea, dysentery, skin infections, and anemia [1,2]. Moreover, this plant has also been used as one of Thai folk medicine recipes for the treatment of benign prostatic hyperplasia (BPH) in the North of Thailand. However, there is no scientific report of active compounds which could be responsible for the treatment of $\mathrm{BPH}$ in this plant.

Several types of secondary metabolites isolated from C. sappan have been reported such as xanthones [2,3], coumarins [3], chalcones [3], flavones [4], homoisoflavonoids [3-7], and diterpenes [8]. Although many chemical constituents and pharmacological activities of C. sappan have been reported such as anti-inflammatory $[4,5,9,10]$, antioxidant [11,12], antibacterial activities [12], cytotoxicity against human cell lines [13,14]. and cardioprotective effect [15], there have been no records about cytotoxicity against leukemic cell lines as well as gas chromatography-mass spectrometry (GC-MS) analysis of phytochemicals in dichloromethane extract that could contribute the medicinal property of this plant.

In this report, the investigation of dichloromethane extract by GC-MS and column chromatography is described together with the cytotoxic effects of isolated compounds on KG1 and KG1a cells. This study provides scientific data of active compounds which confirm the traditional medical use of this plant for the treatment of BPH in Thailand. Moreover, GC-MS analysis of dichloromethane extract and antileukemic activity of chemical constituents from $C$. sappan is revealed for the $1^{\text {st }}$ time.

\section{MATERIALS AND METHODS}

\section{Plant material}

The heartwood of C. sappan was collected from Lamphun province, Thailand, and identified by Assist. Prof. Dr. Aungkana Inta and a voucher specimen (CMUB39873) has been deposited at the Ethnobotanical Research Section, Chiang Mai University Biology Herbarium, Chiang Mai University, Thailand.

\section{General procedure}

Melting points (m.p.) were measured on digital electrothermal melting apparatus (SANYO $1.0 \mathrm{~A}, 220 / 240 \mathrm{v}, 50$ (65) w). ${ }^{1} \mathrm{H}$ and ${ }^{13} \mathrm{C}$ NMR spectra were recorded on a Bruker DRX 400 spectrometer. IR spectra were obtained using Fourier-transform infrared 4796 spectrometer (Bruker, TENSOR 27). Ultraviolet (UV) spectra were recorded using a Lambda $25 \mathrm{UV} /$ Vis spectrometer (PerkinElmer Instruments). Column chromatography was performed using silica gel 60 (Merck No. 9385, 0.040-0.063 mm). Thin-layer chromatography (TLC) was carried out using Merck silica gel $60 \mathrm{PF}_{254}$ precoated on an aluminum plate, and the compounds were visualized by UV light under the wavelength at $254 \mathrm{~nm}$ and sprayed with $p$-anisaldehyde reagent.

\section{Extraction and isolation}

The air-dried and finely powdered heartwood of C. sappan (1.00 kg) was extracted with dichloromethane at room temperature, successively twice over a period of 3 days. Removal of solvent under reduced pressure afforded the dichloromethane extract (12.67 g) of C. sappan.

The dichloromethane extract (10.63 g) was separated by column chromatography over silica gel, using a stepwise gradient elution of 
hexanes-acetone ( $400 \mathrm{ml}$ each). Elution started with hexanes, gradually enriched with acetone in hexanes to $100 \%$ acetone, followed by an increasing amount of methanol in acetone, and finally with $100 \%$ methanol. Fractions were collected and combined with TLC behavior under UV light at $254 \mathrm{~nm}$. The solvents were evaporated to dryness to give 14 fractions (A1-A14). Fraction A5 (1.20 g) was further separated by column chromatography on silica gel using hexanes: dichloromethane (8:2) as eluent to afford four subfractions (B1-B4). Fraction B4 contained a mixture of compounds 3 and 4 (52.6 mg). Fraction A6 (5.00 g) was fractionated by column chromatography and afforded eight subfractions (C1-C8). Subfraction C6 was found to contain red gum of compound 1 (289.2 mg). Subfraction B1 was further purified on silica gel column, eluting with hexanes:ethyl acetate (9:1) to afford compound 2 (17 mg).

\section{Identification of compounds by GC-MS analysis}

GC-MS analysis of the dichloromethane extract was carried out using a high resolution on a mass spectrometer of Agilent 19091S-433E $325^{\circ} \mathrm{C}$ Max. Compounds were separated on HP-5MS capillary column $(30.0 \mathrm{~m} \times 250 \mu \mathrm{m})$ coated with $0.25 \mu \mathrm{m}$ film thickness of $5 \%$ phenyl methyl siloxane. The oven temperature was $60-280^{\circ} \mathrm{C}$ at $5^{\circ} \mathrm{C} / \mathrm{min}$. The split injection was conducted with a split ratio of 50:1. Helium was used as the carrier gas at flow rate $1.0 \mathrm{ml} / \mathrm{min}$. MS condition performed with ionization mode, ion source of $230^{\circ} \mathrm{C}$, mass range 29-500 amu. Compounds were identified using NIST98 and Wiley275-library spectra.

\section{Cytotoxicity}

KG1 cells and KG1a cells were chosen as cancer cell line models to test cell cytotoxicity. Both cells are human acute myeloid leukemia and were purchased from ATCC, USA. Cells $\left(1.0 \times 10^{4}\right.$ cells/well $)$ were seeded into a 96-well plate and incubated for overnight at $37^{\circ} \mathrm{C}$ and $5 \%$ of $\mathrm{CO}_{2}$. Then, cells were treated with compounds 1-4 at final concentrations of $3.125,6.25,12.5,25,50$, and $100 \mu \mathrm{g} / \mathrm{ml}$, and dimethyl sulfoxide (DMSO) in complete medium was used as a vehicle control for another $48 \mathrm{~h}$. Subsequently, $15 \mu \mathrm{l}$ of $0.2 \mathrm{mg} / \mathrm{ml}$ MTT dye solution was added into each well, incubating for $4 \mathrm{~h}$. MTT dye could change dehydrogenase enzyme from viable mitochondria to formazan crystals. The formazan crystals were dissolved in $200 \mu \mathrm{l}$ of DMSO, and the absorbance values of the solutions were measured at $578 \mathrm{~nm}$ on a microplate reader (Metertech, Taipei, Taiwan), using the wavelength of $630 \mathrm{~nm}$ as a reference. The percentage of cell viability was calculated by the following equation.

$\%$ cell viability $=\frac{\text { OD average of tested well }}{\text { OD average of vehicle control }} \times 100$

The results of three experiments were drawn to the average relation graphs between concentrations and percent cell viability.

\section{RESULTS}

The phytochemical compounds in dichloromethane extract from the heartwood of $C$. sappan were analyzed by the GC-MS method. The mass analysis revealed the presence of 14 compounds as shown in Table 1.

The dichloromethane extract was further investigated by column chromatography. The investigation resulted in the isolation of two compounds (1-2) and one mixture of compounds 3 and 4 . The isolated compounds were identified by spectroscopic methods together with the comparison with those data previously reported in the literature. Their structures are shown in Fig. 1.

The isolated compounds from C. sappan, compounds $1-2$ as well as the mixture of 3 and 4, were evaluated for their cytotoxic effect on KG1 and KG1a cells.

After leukemic cell lines were treated with compounds 1-4 at various concentrations for $48 \mathrm{~h}$, the cytotoxic effects were investigated using MTT assay. Cytotoxicity of compounds $1-4$ was determined by $\mathrm{IC}_{50}$ values. The $\mathrm{IC}_{50}$ values of compounds $1-2$ and the mixture of 3 and 4

Table 1: The GC-MS analysis presented the phytochemical compounds in dichloromethane extract from the heartwood of C. sappan

\begin{tabular}{|c|c|c|}
\hline Compounds $^{\mathrm{a}}$ & $\begin{array}{l}\text { Retention } \\
\text { time } \\
\text { (min) }\end{array}$ & $\begin{array}{l}\% \text { Relative } \\
\text { peak } \\
\text { abundance }\end{array}$ \\
\hline \multicolumn{3}{|l|}{ Phenolics } \\
\hline 3-Allyl-6-methoxyphenol & 25.6 & 0.25 \\
\hline $\begin{array}{l}\text { 4-Hydroxy-3-methoxybenzaldehyde } \\
\text { (Vanillin) }\end{array}$ & 27.3 & 0.22 \\
\hline $\begin{array}{l}\text { 4-Hydroxy-3,5-dimethoxybenzaldehyde } \\
\text { Terpenoids }\end{array}$ & 37.5 & 0.38 \\
\hline Squalene & 71.0 & 1.22 \\
\hline Friedelan-3-one (Friedelin) & 87.8 & 5.80 \\
\hline alpha-Tocopherol (Vitamin E) & 77.6 & 0.33 \\
\hline \multicolumn{3}{|l|}{ Fatty acid } \\
\hline Tetradecanoic acid & 41.5 & 0.94 \\
\hline n-Hexadecanoic acid & 48.5 & 7.46 \\
\hline $\begin{array}{l}\text { (9Z,12Z)-Octadeca-9,12-dienoic acid } \\
\text { (Linoleic acid) }\end{array}$ & 53.9 & 14.9 \\
\hline \multicolumn{3}{|l|}{ Esters } \\
\hline p-Methoxycinnamic acid ethyl ester & 40.8 & 0.10 \\
\hline Benzyl benzoate & 41.1 & 0.32 \\
\hline \multicolumn{3}{|l|}{ Sterols } \\
\hline Campesterol & 79.4 & 3.84 \\
\hline $\begin{array}{l}\text { Stigmasta-5,22-dien-3-ol } \\
\text { (Stigmasterol) }\end{array}$ & 80.1 & 4.58 \\
\hline $\begin{array}{l}\text { 22,23-Dihydrostigmasterol } \\
(\beta \text {-Sitosterol) }\end{array}$ & 81.7 & 13.1 \\
\hline
\end{tabular}

a\% matching $<80 \%$ is not considered. GC-MS: Gas chromatography-mass spectrometry, C. sappan: Caesalpinia sappan

Table 2: The $\mathrm{IC}_{50}$ values of compounds 1-2 and the mixture of 3 and 4 on KG1 and KG1a cell lines

\begin{tabular}{lll}
\hline Compounds & IC $_{\mathbf{5 0}}(\mu \mathbf{g} / \mathbf{m l})$ & \\
\cline { 2 - 3 } & $\mathbf{K G 1}$ & KG1a \\
\hline 1 & $13.30 \pm 0.49$ & $12.24 \pm 1.08$ \\
2 & $>100$ & $>100$ \\
3 and 4 & $>100$ & $>100$ \\
\hline
\end{tabular}

Data are the mean values \pm SEM of three independent experiments. SEM: Standard error of mean

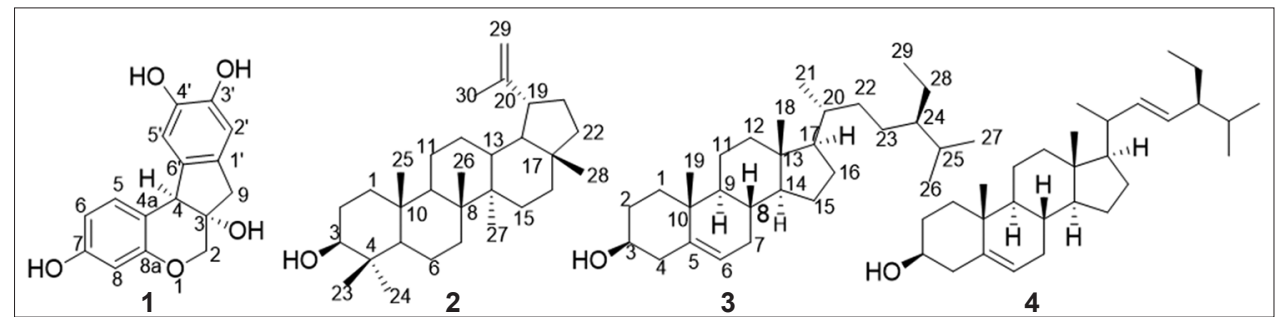

Fig. 1: Structures of compounds 1-4 isolated from the heartwood of $C$. sappan 
on KG1 cells were $13.30 \pm 0.49,>100$, and $>100 \mu \mathrm{g} / \mathrm{ml}$, respectively. The IC $\mathrm{I}_{50}$ values on KG1a were very close to KG1 cells with the values of $12.24 \pm 1.08,>100$, and $>100 \mu \mathrm{g} / \mathrm{ml}$, respectively (Table 2 ).

\section{DISCUSSION}

In this study, 14 compounds have been detected in the dichloromethane extract from the heartwood of $C$. sappan by GC-MS analysis. Linoleic acid and $\beta$-sitosterol were found to be the major compounds presenting in $14 \%$ and $13 \%$, respectively. Linoleic acid has possessed many biological activities such as anti-inflammatory, hypocholesterolemic cancer preventive, nematicide insectifuge, hepatoprotective, antihistamines, antiacne, antiarthritis, antieczemic, 5-alpha-reductase inhibitor, antiandrogenic, and anticoronary [16]. While the $\beta$-sitosterol also found the main compound in this plant has been reported the ability in the reduction of the growth and the multiplication on prostate cancer cell lines [17-19]. From the GC-MS analysis results, these major compounds could be responsible for the medicinal properties which support $C$. sappan for the treatment of BPH.

For the further phytochemical investigation, the dichloromethane extract was separated by column chromatography to afford compounds 1-2 and the mixture of 3 and 4 .

Compound 1 was isolated as red gum. The ${ }^{1} \mathrm{H}$ NMR signals at $\delta 2.77$ $(\mathrm{d}, 1 \mathrm{H})$ and $2.97 \mathrm{ppm}(\mathrm{d}, 1 \mathrm{H})$ assigned to methylene protons of the cyclopentane ring which were confirmed by the germinal coupling constant of $15.7 \mathrm{~Hz}$. The methylene protons of $\mathrm{C}-2$ attached to the oxygen atom of pyran ring were resonated at $\delta 3.67(\mathrm{~d}, 1 \mathrm{H})$ and $3.90 \mathrm{ppm}(\mathrm{d}, 1 \mathrm{H})$ with the germinal coupling constant of $11.2 \mathrm{~Hz}$. The group of aromatic proton signals at $\delta 7.16(\mathrm{~d}, 1 \mathrm{H}, J=8.3 \mathrm{~Hz}), 6.45(\mathrm{dd}$, $1 \mathrm{H}, J=8.3,2.5 \mathrm{~Hz}), 6.26(\mathrm{~d}, 1 \mathrm{H}, J=2.5 \mathrm{~Hz}), 6.61(\mathrm{~s}, 1 \mathrm{H})$, and $6.73 \mathrm{ppm}(\mathrm{s}$, $1 \mathrm{H})$ was referred to $\mathrm{H}-5, \mathrm{H}-6, \mathrm{H}-8, \mathrm{H}-2$ ', and $\mathrm{H}-5$ ', respectively.

The ${ }^{13} \mathrm{C}$ NMR spectrum displayed 16 signals for 16 carbons, which were confirmed the molecular formula of $\mathrm{C}_{16} \mathrm{H}_{14} \mathrm{O}_{5}$ of brazilin. Compound 1 was proved to be brazilin by comparison of its ${ }^{1} \mathrm{H}$ and ${ }^{13} \mathrm{C}$ NMR spectral data with the literature $[2,7]$.

Compound 2 was obtained as white amorphous solid, m.p. $210-212^{\circ} \mathrm{C}$. The ${ }^{1} \mathrm{H}$ NMR ( $400 \mathrm{MHz}, \mathrm{CDCl}_{3}$ ) spectrum displayed the presence of seven tertiary methyl groups at $\delta 0.76\left(\mathrm{~s}, 24-\mathrm{CH}_{3}\right), 0.79\left(\mathrm{~s}, 28-\mathrm{CH}_{3}\right), 0.83(\mathrm{~s}, 25-$ $\left.\mathrm{CH}_{3}\right), 0.94\left(\mathrm{~s}, 27-\mathrm{CH}_{3}\right), 0.97\left(\mathrm{~s}, 23-\mathrm{CH}_{3}\right), 1.03\left(\mathrm{~s}, 26-\mathrm{CH}_{3}\right)$, and $1.68 \mathrm{ppm}$ $\left(\mathrm{s}, 30-\mathrm{CH}_{3}\right)$. The signal at $\delta 3.20 \mathrm{ppm}(\mathrm{dd}, 1 \mathrm{H}, J=5.2,11.1 \mathrm{~Hz})$ indicated the presence of methine proton $\mathrm{H}-3$ connected with a hydroxyl group and the signal at $\delta 2.38 \mathrm{ppm}(\mathrm{dt}, 1 \mathrm{H}, J=5.7,11.0 \mathrm{~Hz})$ was referred to $\mathrm{H}-19$. The olefinic methylene protons appeared at $\delta 4.57$ (s, 1H, H-29a) and $4.69 \mathrm{ppm}(\mathrm{s}, 1 \mathrm{H}, \mathrm{H}-29 \mathrm{~b})$. These results suggested that compound 2 was lupeol, a pentacyclic triterpene, by comparison of its ${ }^{1} \mathrm{H}$ NMR data with those previously reported in the literature [20].

The mixture of compounds 3 and 4 was obtained colorless plates which were characterized as $\beta$-sitosterol and stigmasterol, respectively, by analysis of ${ }^{1} \mathrm{H}$ NMR spectrum. The signal at $5.37 \mathrm{ppm}(\mathrm{d}, 1 \mathrm{H}, J=5.2 \mathrm{~Hz})$ was assigned as olefinic proton $\mathrm{H}-6$, and the signal appeared at $\delta$ $3.55 \mathrm{ppm}(\mathrm{m}, 1 \mathrm{H})$ was assigned to $\mathrm{H}-3$ connected to the hydroxyl group for both $\beta$-sitosterol and stigmasterol. The signals at $5.17 \mathrm{ppm}(\mathrm{dd}$, $0.47 \mathrm{H}, J=15.1,8.6 \mathrm{~Hz}$ ) and $5.03 \mathrm{ppm}(\mathrm{dd}, 0.48 \mathrm{H}, J=15.2,8.8 \mathrm{~Hz}$ ) were assigned to $\mathrm{H}-22$ and $\mathrm{H}-23$ of stigmasterol. The ratio of the mixture of $\beta$-sitosterol and stigmasterol was estimated around 1:1 by determining the integration of $\mathrm{H}-6, \mathrm{H}-22$, and $\mathrm{H}-23$ which appeared in the ratio of 1.00:0.47:0.48. The mixture of compounds 3 and 4 was proved to contain $\beta$-sitosterol and stigmasterol by comparison of their ${ }^{1} \mathrm{H}$ NMR data with those previously reported in the literature $[21,22]$.

The isolated compounds 1-4 were evaluated for cytotoxic activity on KG1 and KG1a cells. Among these compounds, brazilin (1), a homoisoflavonoid, showed the most cytotoxic effect on both leukemic cell lines. Hung et al. [23] revealed that the methanol extract of $C$. sappan exhibited cytotoxic activity against several of the cancer cell lines.
Moreover, sappanchalcone, a flavonoid isolated from C. sappan, has been reported to inhibit oral cancer cell growth and caesalpiniaphenol $\mathrm{G}-\mathrm{H}$, two phenolic compounds isolated from Vietnamese $C$. sappan, displayed potent inhibitory activity against HL-60 cancer cell lines [13]. Brazilin and its analogs have also been reported cancer-preventive qualities toward several human cancer cell lines such as HT29, A549, HL60, and K562 in MTT assay [24]. Our results were agreed with the previous reports. The extract and isolated compounds, especially phenolic compounds, from $C$. sappan showed an ability to inhibit the growth of several cancer cells $[13,23,24]$. Therefore, this study presents that brazilin (1) could be a potential anticancer property against leukemia cells and reveals the first analysis of isolated compounds from C. sappan with cytotoxicity on leukemic cell lines.

\section{CONCLUSION}

The GC-MS analysis of the dichloromethane extract from C. sappan revealed many groups of phytochemical compounds, including phenolics, terpenoids, fatty acid, esters, and sterols. Linoleic acid and $\beta$-sitosterol found to be the major compounds. Moreover, the $\beta$-sitosterol has been reported to possess anti-BPH property which confirms the traditional medical use in Thailand. The brazilin (1), a major compound from C. sappan, shows cytotoxicity on leukemia cells, which could be a potential anticancer property.

\section{ACKNOWLEDGMENT}

We would like to thank the Department of Chemistry and Faculty of Science, Chiang Mai University, for the financial support. We are also grateful to Assist. Prof. Dr. Aungkana Inta, Department of Biology, Chiang Mai University, for identification of plant material.

\section{REFERENCES}

1. Sireeratawong S, Piyabhan P, Singhalak T, Wongkrajang Y, Temsiririrkkul R, Punsrirat J, et al. Toxicity evaluation of sappan wood extract in rats. J Med Assoc Thai 2010;93 Suppl 7:S50-7.

2. Nirmal NP, Rajput MS, Prasad RG, Ahmad M. Brazilin from Caesalpinia sappan heartwood and its pharmacological activities: A review. Asian Pac J Trop Med 2015;8:421-30.

3. Chen YP, Liu L, Zhou YH, Wen J, Jiang Y, Tu PF. Chemical constituents from Sappan lignum. J Chin Pharm Sci 2008;17:82-6.

4. Pawar CR, Landge AD, Surana SJ. Phytochemical and pharmacological aspects of Caesalpinia sappan. J Pharm Res 2008;1:131-8.

5. Zhao MB, Li J, Shi SP, Cai CQ, Tu PF, Tang L, et al. Two new phenolic compounds from the heartwood of Caesalpinia sappan L. Molecules 2014;19:1-8

6. Namikoshi M, Nakata H, Saitoh T. Homoisoflavonoids from Caesalpinia sappan. Phytochemistry 1987;26:1831-3.

7. Namikoshi M, Nakata H, Yamada H, Nakai M, Saitoh T. Homoisoflavonoids and Related compounds II. 1). Isolation and absolute configurations of 3, 4-dihydroxylated homoisoflavan and brazilins from Caesalpinia sappan L. Chem Pharm Bull 1987;35:2761-73.

8. Nguyen HX, Nguyen MT, Nguyen TA, Nguyen NY, Phan DA, Thi PH, et al. Cleistanthane diterpenes from the seed of Caesalpinia sappan and their ant austerity activity against PANC-1 human pancreatic cancer cell line. Fitoterapia 2013;91:148-53.

9. Jeong IY, Jin CH, Park YD, Lee HJ, Choi DS, Byun MW. Antiinflammatory activity of an ethanol extract of Caesalpinia sappan L. in LPS-induced RAW 264.7 cells. J Food Sci Nutr 2008;13:253-8.

10. Sasaki Y, Hosokawa T, Nagai M, Nagumo S. In vitro study for inhibition of NO production about constituents of Sappan lignum. Biol Pharm Bull 2007;30:193-6.

11. Safitria R, Tarigana P, Freislebenb HJ, Rumampukc RJ, Murakamid A. Antioxidant activity in vitro of two aromatic compounds from Caesalpinia sappan L. BioFactors 2003;19:71-7.

12. Kadchumsang S, Sirisa-ard P, Sookkhee S, Chansakaow S. Antibacterial and Antioxidant activities of lanna medicinal plants used in mahoog formula. Int J Pharm Pharm Sci 2015;7:366-70.

13. Hung TM, Hai NX, Nhan NT, Quang TT, Quan TL, Cuong TD, et al. Cytotoxicity of new phenolic compounds from vietnamese Caesalpinia sappan. Biosci Biotechnol Biochem 2013;77:2378-82.

14. Laksmiani NP, Susidarti RA, Meiyanto E. Brazilein increases the sensitivity of doxorubicin on MCF-7 resistant doxorubicin (MCF-7/ 
DOX) cells through inhibition of HER-2 activation. Int J Pharm Pharm Sci 2015;7:525-8

15. Nugraheni K, Saputri FC. The effect of secang extract (Caesalpinia sappan Linn) on the weight and histology appearance of white male rats' heart induced by isoproterenol. Int J Appl Pharm 2017;9:59-61.

16. Sermakkani M, Thangapandian V. GC-MS analysis of Cassia italica leaf methanol extract. Asian J Pharm Clin Res 2012;5:90-4.

17. Bennani H, Drissi A, Giton F, Kheuang L, Fiet J, Adlouni A. Antiproliferative effect of polyphenols and sterols of virgin Argan oil on human prostate cancer cell lines. Cancer Detect Prev 2007;31:64-9.

18. Klippel KF, Hiltl DM, Schipp B. A multicentric, placebo-controlled, double-blind clinical trial of beta-sitosterol (phytosterol) for the treatment of benign prostatic hyperplasia. German BPH-Phyto study group. Br J Urol 1997;80:427-32.

19. Wilt TJ, MacDonald R, Ishani A. Beta-sitosterol for the treatment of benign prostatic hyperplasia: A systematic review. BJU Int 1999;83:976-83.
20. Fotie J, Bohle DS, Leimanis ML, Georges E, Rukunga G, Nkengfack AE. Lupeol long-chain fatty acid esters with antimalarial activity from Holarrhena floribunda. J Nat Prod 2006;69:62-7.

21. De-Eknamkul W, Potduang B. Biosynthesis of $\beta$-sitosterol and stigmasterol in Croton sublyratus proceeds via a mixed origin of isoprene units. Phytochemistry 2003;62:389-98

22. Forgo P, Kover KE. Gradient enhanced selective experiments in the ${ }^{1} \mathrm{H}$ NMR chemical shift assignment of the skeleton and sidechain resonances of stigmasterol, a phytosterol derivative. Steroids 2004;69:43-50.

23. Hung TM, Dang NH, Dat NT. Methanol extract from vietnamese Caesalpinia sappan induces apoptosis in HeLa cells. Biol Res 2014;47:1-5

24. Lee DY, Lee MK, Kim GS, Noh HJ, Lee MH. Brazilin inhibits growth and induces apoptosis in human glioblastoma cells. Molecules 2013;18:2449-57. 